\title{
Balcony Railings as a Representative Element of Collective Memory: Balcony Railings of Ankara Apartment Blocks
}

\author{
By Zeynep Tuna Ultav*
}

Specialty about balcony as a building element is explained through its attribute of connecting different spheres that are public and private, the individual and collective, the indoor and outdoor (BK at the Biennale: anatomy of a balcony, 2014). Regarding it as the border between public and private, the individual and collective, the indoor and outdoor; this study aims to display the role of balcony railings of modern apartment block typology that developed rapidly through Flat Ownership Law in 1965, as a representative element of collective memory. Thus, the year 1965 marks a turning point in terms of housing production that in turn defines the new face of Ankara streets. The standardization of the apartment block due to the limitations of urban parcels forced architects or builders to search for means of breaking the monotony of this new face. One of the subsidiary elements were iron balcony railings that could be defined as "industrialized ornament". They act as a retouching in an industrial way in order to aesthetize what is very ordinary. This tactic of building supports Heynen's idea of dwelling, as in the first instance being associated with tradition, security, and harmony. ${ }^{l}$ The aesthetized balcony railings are a response to the dilemma created by the ordinary apartment block typolog and the idea of dwelling. The representative role of balcony railings will be exhibited through an archival study on balcony railings of Ankara, in which nine districts (Bahçelievler, Emek, Anittepe, Maltepe, Kızılay, Küçükeast, Kavaklıdere, Gaziosmanpaşa, Çankaya) were selected as the case study. Around 1900 apartment buildings built between 1950 and 1975 that carried the characteristics of "modernized ornament" were photographed and the photographs were categorized according to the following criteria: style, form, material, details, use of color, etc. In parallel with Durkheim's belief that every society exhibits and requires a sense of continuity with the past, ${ }^{2}$ this study aims to reveal that the archival of these railings as a representative element would remind Ankara dwellers of their shared memory.

\section{Introduction}

Durkheim views the significance of memory in holding societies together and in sustaining the transmission of values. ${ }^{3}$ As suggested by Misztal (2013), "memory stabilizes subjects and constitutes the present; [and] it is the name we give to the faculty that sustains continuity in collective and in individual

\footnotetext{
*Associate Professor, Yaşar University, Turkey.

1. Hilde Heynen, The Architecture and Modernity. A Critique (Cambridge: The MIT Press, 1999).

2. Barbara Misztal, Theories of Social Remembering (Berkshire: Open University Press, 2013).

3. Ibid.
} 
experience" (117), and that every society exhibits and requires a sense of continuity with the past.

As stated by Altan Ergut (2009), research on collective memory studies should not be confined to canons or monumental buildings and/or structures. Departing from this idea, this study aims to reveal that balcony railings of Ankara apartment blocks (1950-75) should take attraction in terms of their place within the memory of the city dwellers.

Specialty about balcony as a building element is explained through its attribute of connecting different spheres that are public and private, individual and collective, indoor and outdoor (BK at the Biennale: anatomy of a balcony, 2014). This study aims to display the role of balcony railings of modern apartment block typology that emerged in Flat Ownership Law (Kat Mülkiyet Kanunu) in 1965, as a representative element of collective memory. 1965 marks a turning point in terms of housing production that in turn defines the new face of Ankara streets. The standardization of the apartment block due to the limitations of urban parcels forced architects or builders to search for means of breaking the monotony of this new face. One of the subsidiary elements were iron balcony railings that could be defined as "industrialized ornament". They act as a retouching in an industrial way in order to aesthetize what is very ordinary. ${ }^{4}$ This tactic of building supports Heynen's idea of dwelling, as in the first instance being associated with tradition, security, and harmony. ${ }^{5}$ The aesthetized balcony railings are a response to the dilemma created by the ordinary apartment block typology and the idea of dwelling.

\section{The Significance of Balcony Railings in terms of Collective Memory}

Façade determines the appearance of a building; it can be observed from outside like an image. Balcony is an important element of the apartment block typology as well as of its component, namely façade. However, "balcony" is also occasionally criticized for being unnecessary gaps due to zoning regulations arising from necessity. ${ }^{6}$ It has been the subject of the exhibition at the international architecture exhibition of the Venice Architecture Biennale (7 June-23 November 2014) illustrated through photos, maps, models and life-size balconies (see Figure 1). Koolhaas (2014) points out the significance of balcony also in terms of politics: "Without the balcony, the history of the world would have looked completely different." "What is special about the balcony is that it is an element that connects different spheres: "It links up the public and private, the individual and collective, the indoor and outdoor."

4. Ali Cengizkan, Modernin Saati (Ankara: Mimarlar Derneği 1927 ve Boyut Yayın Grubu, 2002).

5. Heynen, The Architecture and Modernity. A Critique. 1999.

6. Mehmet Hamuroğlu, "Balkonlar Üzerine,” Ege Mimarlik94, no. 1 (1994): 39.

7. As cited in BK at the Biennale: Anatomy of a Balcony. (2014) https://www.tudelft.nl/en/ 2014/bk/bk-at-the-biennale-anatomy-of-a-balcony/. [Accessed October 25, 2018].

8. Avermaete, 2014 as cited in BK at the Biennale: Anatomy of a Balcony, 2014. 


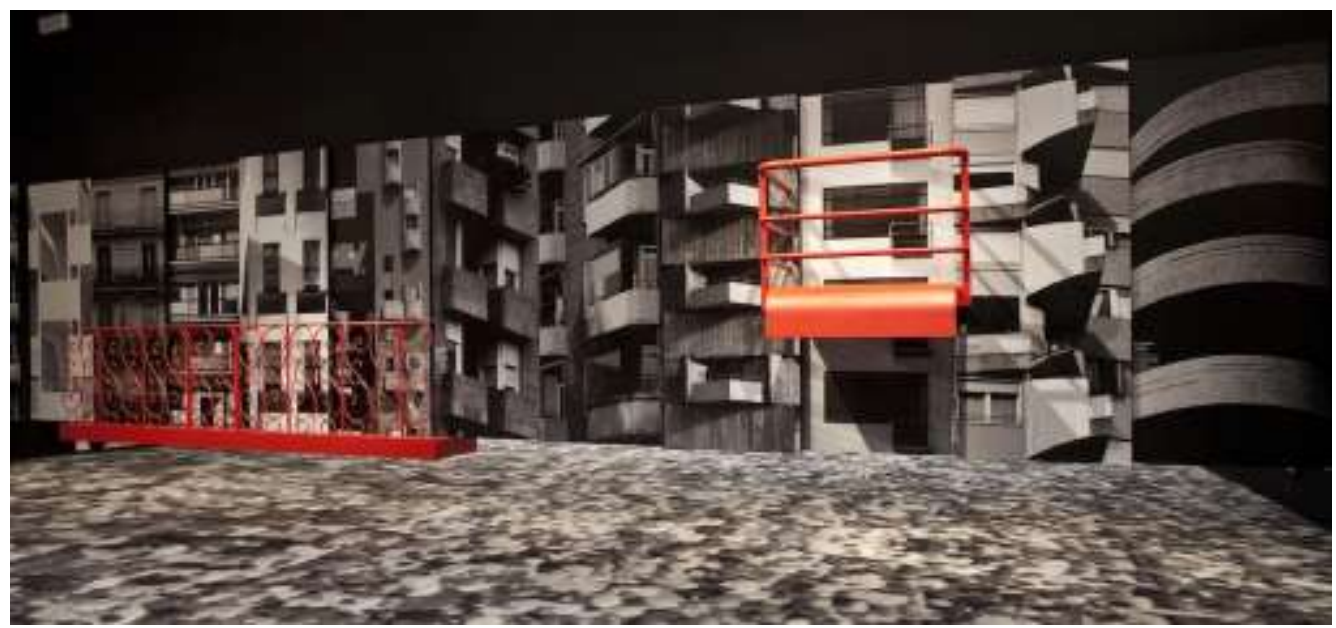

Figure 1. Balcony Exhibition in Venice Architecture Biennale 2014

Source: http://www.labiennale.org/en/architecture/2014/biennale-architettura-2014.

It is not wrong to state that neither balcony as an architectural element nor railings as its component have been a considerable issue within the relevant literature. One of the rarest references in this area is Istanbul'un Balkonlart "İstanbul's Balconies" by Şengör and Barka (2004). Major attention to balcony railings has been given through the Exhibition, "The Balustrades of Beirut", organized in Beirut by Architect Mazen Heidar in order to take attraction to modern balcony railings in the city (see Figure 2).

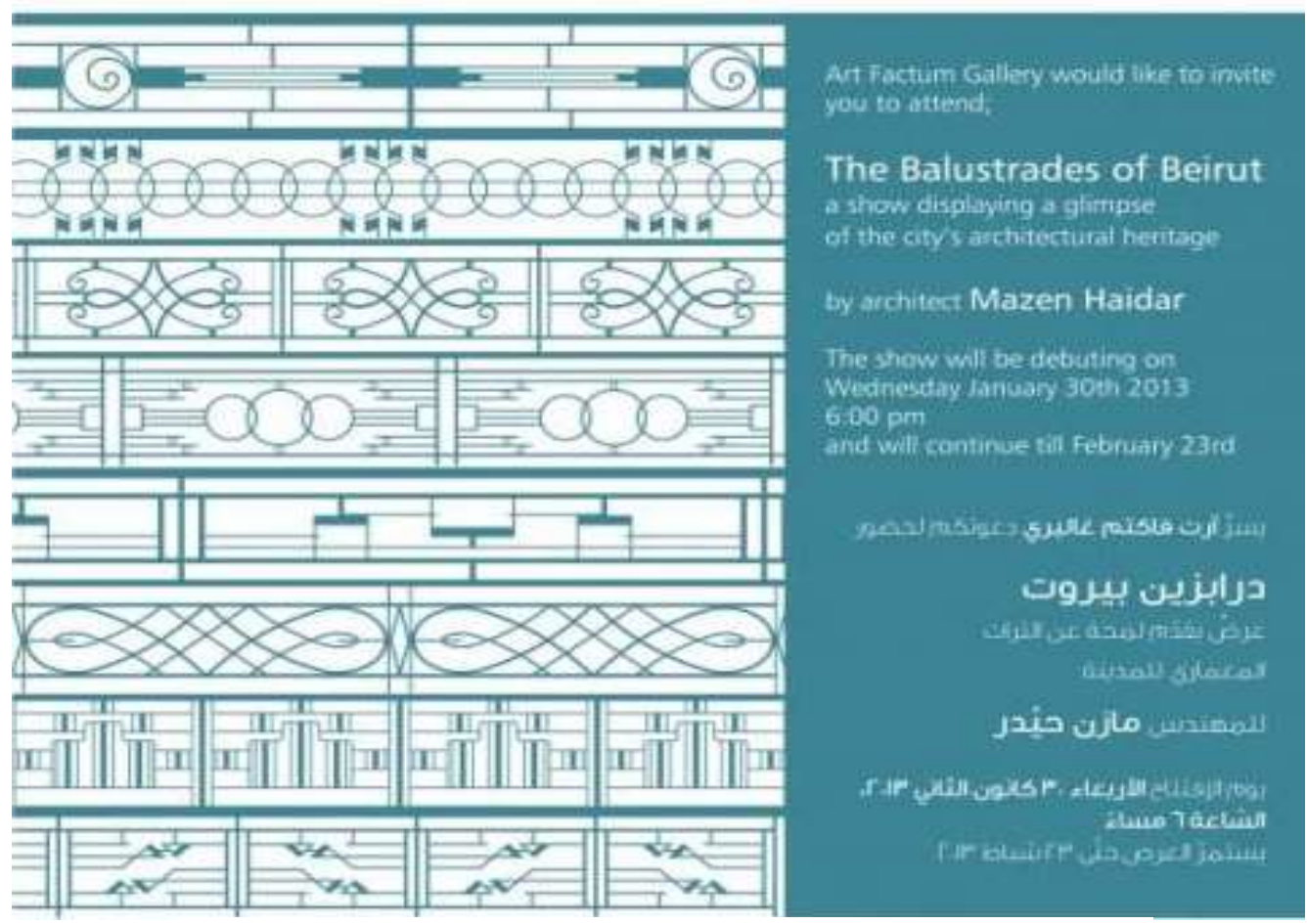

Figure 2. The Balustrades of Beirut Exhibition at Art Factum Gallery

Source: http://www.archileb.com/article.php?id=708. 
The significance of balcony railings in terms of collective memory can be elucidated in several aspects, two of which are highlighted in this study:

- In terms of rapid growth of apartment block typology.

- In terms of its role as "ornament".

\section{In Terms of Rapid Growth of Apartment Block Typology}

In Turkey, the elections of 1950 not only mark the end of the early republican era in favor of the more liberal economics and populist politics of the Democrat Party, but also bear the legacy of high modernism in architecture and urbanism: ${ }^{9}$

Throughout the 1950s, the need for urban housing in response to massive migration to major cities from the countryside remained a monumental social, economic and political challenge for the DP government. Just to cite some figures, Turkey's urban population, which grew by 20.1 percent in the decade 1940-1950, reached a growth rate of 80.2 percent between 1950 and 1960 . Real Estate and Credit Bank (Emlak Kredi Bankası) was established with the explicit purpose of financing urban housing, and the first collective housing typologies emerged featuring reinforced concrete slab block construction. ${ }^{10}$

Separating the proprietorship on a single plot was only possible until the point that two regulations went into law: The Title Deed Law (Тари Капипи) in 1954 and Flat Ownership Law (Kat Mülkiyet Kanunu) in 1965. ${ }^{11}$ Thus, the 1950s witnessed an expansion in multi-story concrete apartment building construction and major endeavors of urban renewal projects, impacted by modernism in architecture. The increase in the number of Apartment building constructions increased rapidly after Turkey's Flat Property Legislation of 1965, whose foundations were laid in the 1950s and early 1960s. Permitting individual ownership of apartments in a building, this enactment fostered the build-sell model and the ensuing production of apartment buildings as anonymous objects: "12 "In this model, the contractor took property from the owner in exchange for flats. The expenses of construction were met by pre-selling the apartments. The possibility of construction with little capital, then, made this model prevalent in other locations as well."13

Being extensive and prevailing, the Apartment Block has verified the success

9. Sibel Bozdoğan, "Turkey’s Post-War modernism. A Retrospective Overview of Architecture, Urbanism and Politics in the 1950s," in Mid-Century Modernism in Turkey: Architecture across Cultures in the 1950s and 1960s (ed.) Meltem Ö. Gürel (New York and London: Routledge, 2016).

10. Ibid, 17.

11. Ürger, Ahmet Mucip. "Apartment Block as the Object of the Generic City." Master Thesis. Middle East Technical University, 2004

12. Meltem Ö. Gürel, "Seashore Readings: The Road from Sea Baths to Summerhouses in Mid-Twentieth Century Izmir," in Mid-Century Modernism in Turkey: Architecture across Cultures in the 1950s and 1960s (ed.) Meltem Ö. Gürel (New York and London: Routledge, 2016).

13. Ibid, 42. 
of the "generic" forms of the $20^{\text {th }}$ century urbanization. The unending proliferation of this same "unit" wiped out the target of the Early Republican era for a Modern city. Besides, it has derided the illusionary "urban dream" of this period for "control," and any endeavor for architectural specificity: "In Ankara, the success of the Apartment Block was the materialized evidence for the impossibility of ordering a city with the internal mechanisms of a single discipline." ${ }^{14}$ Whereas the paradigm of modern residential architecture in the early republican era was the single-family house within a garden, the most common typology after 1950 was the reinforced concrete, multi-story apartment building. ${ }^{15} \mathrm{Up}$ to $1950 \mathrm{~s}$, the Apartment Block was viewed as "connoting a high status life", with the ramifications of another modern method for living, in a more crowded neighborhood, and not far to the urban core. However, after 1950s, it has lost its positive connotations becoming an economic phenomenon of property division and being looked down within the framework of architectural debates. ${ }^{16}$ The fast increment of the usage of this new typology expanded in amount and spread everywhere throughout the country in a short period of time. In the next decades, it likewise helped the ascent of a new construction market turning into the generator of new arrangements such as mass housing projects restoring new urban extensions to the city. ${ }^{17}$

One of the main criticisms directed to this phenomenon of 1950's new typology was the inevitable result of "standardization". As stated by Ürger (2004), the first consequence was "the fragmentation of the land due to the parceling policy, and the second one was the fragmentation of the space due to the liberty of flat ownership, which will be major reason for the Apartment Block to lose its identity as a residential building and to transform to a frame." 18 Le Corbusier described housing in terms of standardization in his text Vers Une Architecture (Toward an Architecture) in 1923 as such:

We are at a new age. A new soul. The industry, which has invaded everywhere, like a river that drifts towards its fate, brings us a new spiritual animated vehicle that fits the truth. The economy is governed by laws or unwilling actions ... The problem of the house is a question of age; the social equilibrium is built on this ... We have to create a mood for serial production. From our hearts and minds we can derive static thinking about the home, and if we can look at the problem from a critical and objective point of view, we will arrive at a healthy, ethical and beautiful home car, which is a massproduction house. $^{19}$

Criticisms towards being standardized have been mainly echoed as a result of

\section{Ibid, 9.}

15. Bozdoğan, "Turkey's Post-War modernism. A Retrospective Overview of Architecture, Urbanism and Politics in the 1950s," 2016.

16. Ürger, "Apartment Block as the Object of the Generic City," 2004.

17. Nazan Çapaoğlu, "Home as a 'Place': The Making of Domestic Space at Yeşiltepe Blocks," Master thesis (Middle East Technical University, 2008).

18. Ürger, "Apartment Block as the Object of the Generic City," 2004.

19. Le Corbusier, Bir Mimarlı̆̆a Doğru (İstanbul: Yapı Kredi Yayınları, 2007), 239. 
the radical physical transformation of Ankara after 1950s. The identity of the highly planned capital has been transformed to a generic, which is defined by Ürger as "counter of identity, condition, emphasizing homogenization, blankness and similarity rather than difference": ${ }^{20}$ "The Apartment Block was the object of this condition and the subject of the transformation in the urban identity, both with its physical existence and with the mind-set it has radiated to the whole levels of the society. It has stripped out the identity of the city by its endless reproduction and by disjointing the artifacts, which were the materialization of the Republican Modern identity, like an archipelago.” ${ }^{21}$ The $n$ times repetition of a 'Typical Plan` constitutes an Apartment Block and $\mathrm{n}$ times repetition of the Apartment Block constitutes the city. This repetition and quantity based condition strips the identity and substitutes it with "generic."22 Cengizkan explains this as such: "Unfortunately, housing production in Turkey pursuing the understanding of the spread of different and new discourses, will submit itself to the modern, collectivist, equalitarian, yet gradually ordinary sovereignty of apartment block scheme.,23

Within all these standardized work, there was an element that added dynamism to façades of apartment buildings: Balcony railings. According to Güner (2006), in apartment building typology the only significance of artistic decisions was on the balcony rails. ${ }^{24}$ Apartment buildings, produced with extreme economic solutions, have developed an expressive pattern in which the window-door association behind the thin iron railings, which are generally used as wide balconies among the floor slabs, is considered as a totally transparent façade. The most obvious expression variations that could be seen in these buildings were no more than a few aesthetic experiments on wooden balconies in large horizontal windows, iron balcony railings, or artistic experiments on apartment entrance doors. The apartment balconies that were built in the 1960s to compensate for the artistic missions that architects are increasingly believed to have lost in the massive housing production process. ${ }^{25}$

\section{In Terms of its Role as Ornament}

Davidovici (2004) explains the role of ornamentation on building façade as supporting the tectonics of a building and adding to its aesthetics; seeing its roots in the mannerist notion of façade as veil. Stuhlmacher (2004) states that the multidimensional complexity of architecture made way for two-dimensional textures.

20. Ürger, "Apartment Block as the Object of the Generic City," 2004.

21. Ibid, 7.

22. Ürger, "Apartment Block as the Object of the Generic City," 2004.

23. Cengizkan, "1950'li Y1lllarda Konut: Modernleşme ve Demokratikleşmenin Konut Sorununa Yansimalar1," in Cumhuriyetin Mekanlarl/Zamanları/Insanları (ed.) Elvan Altan Ergut and Bilge İmamoğlu (Ankara: Dipnot Yayınları, 2009).

24. As cited in Alkan Korkmaz, Sevinç, Gizem Özmen, Yasemin Oksel, and Ebru Bengisu, "[En]Closed Balconies: Something Extra," in Proceedings of ARCHDESIGN '15 (ed.) H. Tulum (İstanbul: DAKAM Yayınları, 2015).

25. Güner's concern in his text is the apartment buildings in İzmir, the third largest city of Turkey; however his views can easily be applied for the case of Ankara; Deniz Güner, "İzmir'de Modern Konut Mimarlığı 1950-2006," Planlama 3 (2006). 
The question of whether to use ornaments or not has been a debatable issue since Industrial Age: "For over a century, the controversial issue of ornament has oscillated between the two extreme conditions of being condemned or praised."26 As stated by Healy (2004), "the advance of functionalism made the reception of ornament a needless excess, and the triple analogy within architectural discourse, that can be found in Loos's programmatic rejection of ornament, found in the work of Sullivan an effort to extrapolate from the grammar a meaningful principle of beauty and generation" (42). He further states that:

"In the first instance Loos's rejection needs to be reconsidered, and outlined, within the problematic mimetic theory of functionalism, which with its movement to the inorganic, or rather the non-organic, as Graafland has pointed out, not only required the elimination of, or, liquidation of contradiction (Le Corbusier) but made of ornament a redundancy on two counts; in the first superfluous, because non-working parts for a machine where every component has a function is unimaginable, and with respect to the subjective aesthetic effect, the 'sublime', as absence, does not require such forms."27

According to Loos, ornament is acceptable if it is anonymous, un-authored: "Loos sanctions ornament if it is the product of an older culture- his examples are Persian carpets, Slovak laces, handcraft made by little old ladies- and if it brings pleasure to my fellow human beings." ${ }^{28}$ Loos contended that primitive societies develop toward more refined, reserved, and buildings and products, toward austerity. The utilization of decoration in Modern Architecture, as indicated by Loos, was immoral, crafted by a criminal. ${ }^{29}$ As stated by Davidovici (2004), Tafuri had recognized the difficulty (bordering on impossibility) of pure architectural expression, without recourse to the meanings inherent in its materials and forms. Tafuri defines modem architecture as "pure ${ }^{30}$ architecture, form without utopia, sublime uselessness." 31

One should remember Loos's statement while discussing ornamentation: "Ornamentation means wasted labor and wasted health. That was always the case. Today, however, it also means wasted material, and both mean wasted capital."32 Acting from the reknown proclamation of Adolf Loos, modernism encounters beauty not in included added-on superfluities like ornaments, yet in the plain

26. Deniz Balık and Açalya Allmer, "A Critical Review of Ornament in Contemporary Architectural Theory and Practice," A|Z 13, no. 1 (2016).

27. Patrick Healy, "Ornament? Now," OASE 65 (2004): 42.

28. Christoph Grafe, Mark Pimlott and Mechtild Stuhlmacher, "Editorial," OASE 65 (2004): 4.

29. Korydon Smith, "Ornament and Austerity," in Introducing Architectural Theory: Debating a Discipline (ed.) Korydon Smith (London: Routledge, 2012).

30. The adjective "püre" comes not only from its simplicity and its reduction to primary geometrical forms but also metaphorically from its naivety in lacking of any social as well as historical content; Zeynep Tuna, "Reading Manfredo Tafuri: Architecture and Utopia Design and Capitalist Development," Master thesis (Middle East Technical University, 2002).

31. Manfredo Tafuri, Architecture and Utopia Design and Capitalist Development (Cambridge, Massachusetts and London: the MIT Press, 1976), ix.

32. Adolf Loos, Ornament and Crime: Selected Essays (UK: Ariadne Pr., 1997), 171. 
presentation of the materials themselves. Aside from conveying simplicity to the design, this approach bolsters honesty as respects the materials. A similar honesty is likewise legitimate for communicating every one of the constituents of the buildings. ${ }^{33}$

Functions of surface ornaments can be summarized below:

- Tendency to Give Dynamism to the Façade.

- Transmittance of Pleasure: "Ornament is the only visual art whose primary if not exclusive purpose is pleasure." 34 "Ornaments suggest not only an opening towards a pleasurable world that is elegant, fashionable and different.",35 "Ornament -the elaboration of functionally complete objects for the sake of visual pleasure- has a unique place among the arts." 36

- Readability and Tectonics: The ornament is utilized as an important carrier of meaning that mediates between the mainstream, direct readability and the references to the rich architectonic culture of which it is very deliberately a part. If architects do not prevail with regards to consolidating the mainstream into their work, in being comprehended by people outside the discipline as well, in other words: if architects do not figure out how to take the desires of the public seriously, they will make themselves redundant very quickly. To address this Architecture should without a doubt turn out to be more creative. This makes Schinkel's announcement on the necessity of ornamentation, for the sake of readability, abruptly topical. What's more, the undertaking of the ornament as a mediator and as an aesthetic supporting of an understandable tectonics ends up winning out abstraction and pure cladding. ${ }^{37}$

- Expanding the Formal Repertoire of Architecture: "The experimentation with ornament may be taken, as Tony Fretton has suggested, as just one of several possible attempts to extend the formal repertoire of architecture. None of these experiments can be described as traditionalist.",38

- Communication: "All the while a space and a surface, the interface between the building and the outside world secures a specific autonomy, a three-dimensionality that structures the three-dimensional building itself. In terms of both function and imagery, the façade satisfies the role conventionally assigned to ornament":

33. Suha Özkan, "Modern Türk Mimarlığı için Yeni Bir Giriş," in Modern Turkish Architecture. (ed.) Renata Holod, Ahmet Evin and Suha Özkan (University of Pennsylvania Press, 1984).

34. James Trilling, The Language of Ornament (London and New York: Thames and Hudson, 2001), 14.

35. Mechthild Stuhlmacher, "Vanity and self-will. The Complex, Contradictory Work of Hild Und K," OASE 65 (2004), 26. 2001), 6

36. James Trilling, The Language of Ornament (London and New York: Thames and Hudson, 2004.

37. Stuhlmacher, "Vanity and self-will. The Complex, Contradictory Work of Hild Und K,"

38. Grafe, Pimlott and Stuhlmacher, "Editorial," OASE 65 (2004). 
"The communicative role of ornament, somewhere between text and texture, is explicitly articulated in the tension between (vertical) meaningful reading and (horizontal) visual rhythm, between seeing the façade as a written page and the destruction of its content through repetition and optical patterning." 39

A person who skips the edge of modernity must be frightened in concrete ways from seeing his environment as empty from objects. The same fear should be true for façade design demands embodied in the way that housing exterior spaces are imitated. [...] Architecture has evolved into the world of façades that have no iconographic meaning, which originate in the numerical excess of what they contain, and bear images that are considered sufficiently meaningful that it has only been seen there. Indoor spaces are filled with objects, outdoor spaces are filled with images and bags. The less the meaning of objects, images and pets, the greater the intensity of use of the same objects, images that can have a time meaning. 40

\section{The Case Study: Balcony Railings of Ankara (1950-75)}

The representative role of balcony railings will be exhibited through an archival study on balcony railings of Ankara. Nine modernized districts (Bahçelievler, Emek, Anıttepe, Maltepe, Kızılay, Küçükeast, Ayranc1, Gaziosmanpaşa, Çankaya) were selected as a case study. Around 1900 apartment buildings built between 1950 and 1975 that carried the characteristics of "modernized ornament" were photographed. ${ }^{41}$ The selection of the balcony railings did not have a relationship with the apartment buildings themselves taking granted that the most apartment buildings of the determined period showed similar standardized characteristics. The selection rather depended on the degree of modern character that resulted out of formal qualities of the balcony railings. With their modern character, the visual attributes of the railings did not indicate any relationship with vernacular building culture of Ankara.

There are several reasons for the selection of the city of Ankara for analysis. The first is that, until 1980, Turkey has set the architectural agenda in Ankara. There is an important constructional practice. It was a city suitable for understanding that period and the apartment building and that the republic's capital was a model for all kinds of modernization and renovation. ${ }^{42}$ Ankara has been a model city for the other cities of Turkey from 1928 to 1960 through the original municipality management and its Board of Administration of Construction, whose decisions shaped the urban development.

The features that define this period (1950-1975) can be summarized below:

39. Davidovici, “Abstraction and Artifice," OASE 65 (2004): 118.

40. Uğur Tanyeli, İstanbul 1900-2000. Konutu ve Modernleşmeyi Metropolden Okumak (İstanbul: Akın Nalça Yayınları, 2004).

41. The photographs were categorized according to the following criteria: form, material, details, use of color, etc. Discussion related to this categorization is beyond the limits of this study.

42. Cengizkan, "Özgünlük ve Tekrarın Tekrarı, Konutta Yeni Gelişmeler ve Nesne Olarak Konut,” Arredamento Mimarlık 1 (2004). 
- Rapid population growth. Housing increase. The economy-politics of the 1950-60 period: the beginning of the 1960s' consumer society discourse.

- Development of the construction industry and detailing technology; new and modern values.

- Variety of construction material options.

- Modern evolution from traditional construction workmanship.

- Architectural items are now produced as commodities, and this is the service of this image. Ankara is the vehicle of a newly created housing image.

Balcony railings can be read as the effort to aesthetize the "cubical" through subjective touch on façades (Figures 3-7). Apartment building typology, thus, offers a modern search mixed with ornamentation on the façade image against this standardization. Although, the employment of balcony railings in an "ornamented" grammar refers to a search for creating identity, there are conflicts in the use of railings as ornaments in modern apartment block typology. In the case of balconies, "ornaments" appear as industrialized elements and the railings become the representation of modernized ornament. In this search for a grammar of ornament, it is possible to call railings "retouching", yet "through industrial materials." " In addition, "suddenly the modern abstraction of this architecture is no longer hidden behind its ornamentation but in fact made visible through it."44 Through the repetition of these elements throughout the city -in different districts, it is seen that ornamentation is also standardized and a certain grammar is set.

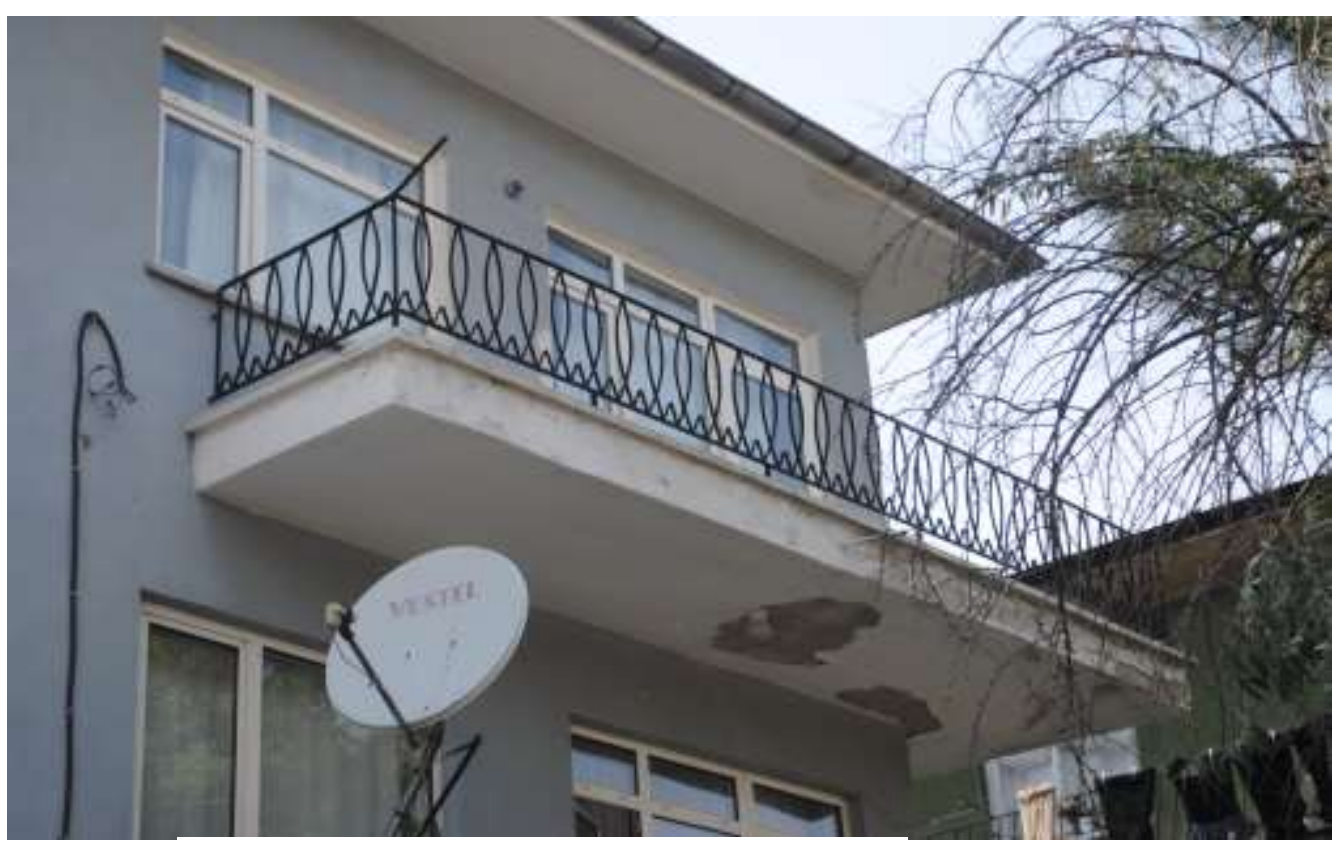

Figure 3. Ankara Balcony Railings, District 1 (Emek)

Source: The author's archive.

43. Ibid, 220.

44. Stuhlmacher, "Vanity and self-will. The Complex, Contradictory Work of Hild Und K," OASE 65 (2004). 


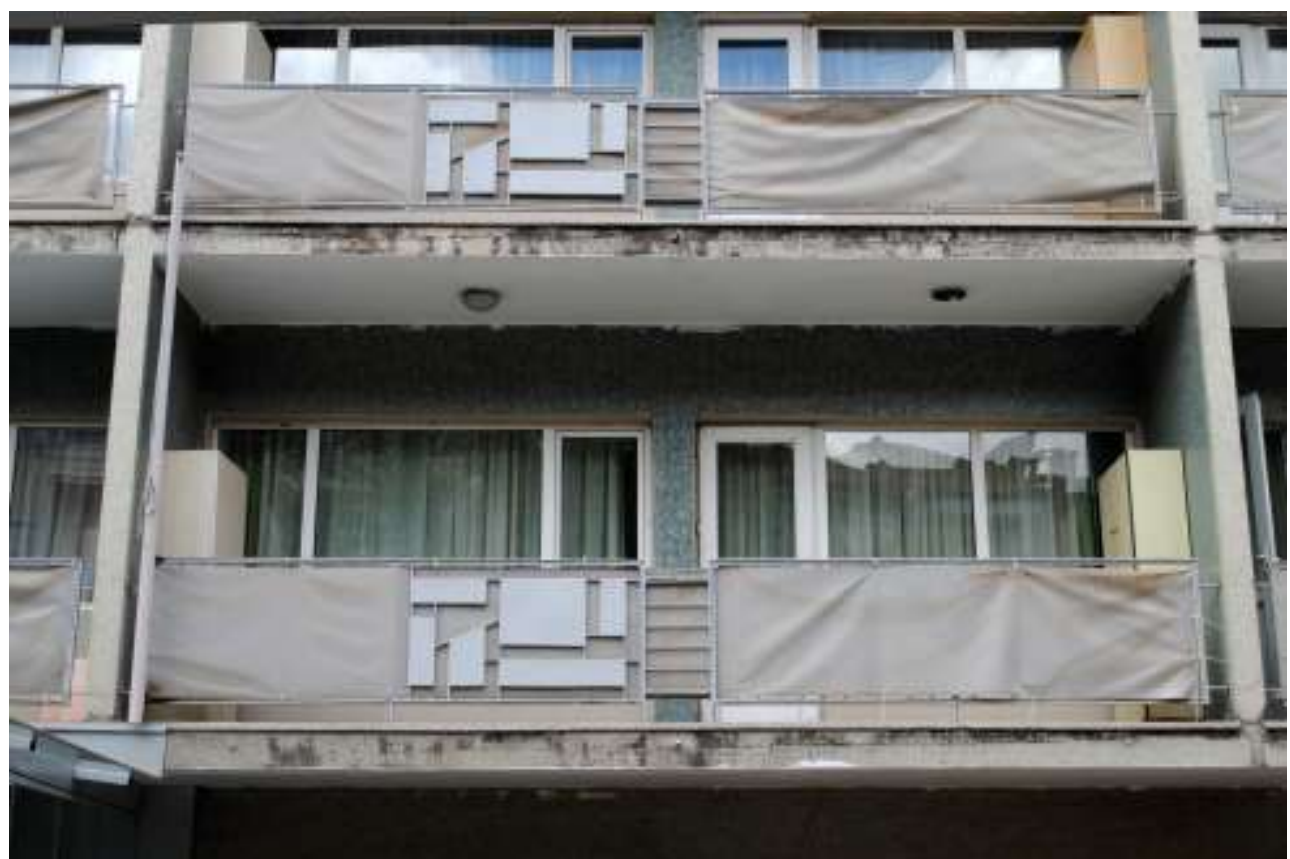

Figure 4. Ankara Balcony Railings, District 2 (Klzılay)

Source: The author's archive.

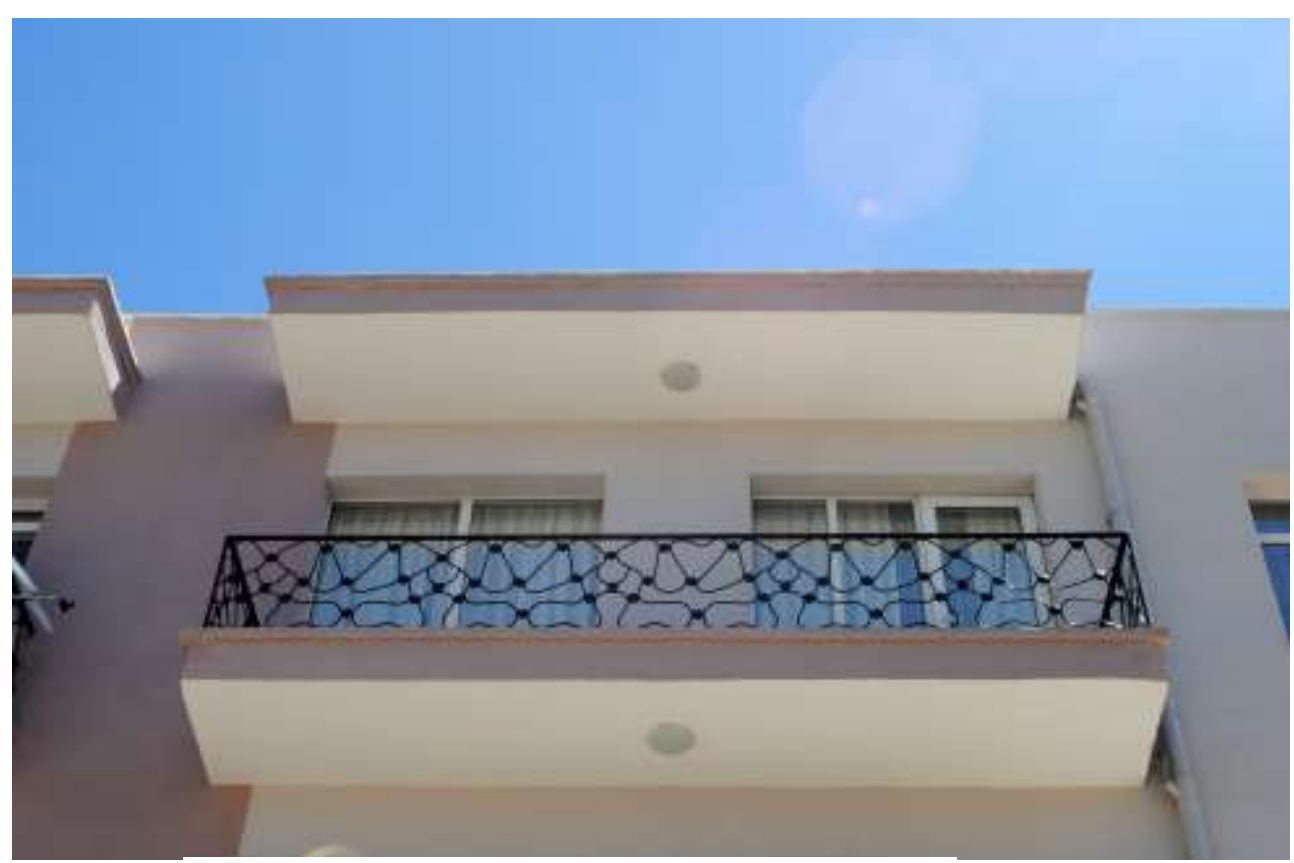

Figure 5. Ankara Balcony Railings, District 3 (Maltepe)

Source: The author's archive. 


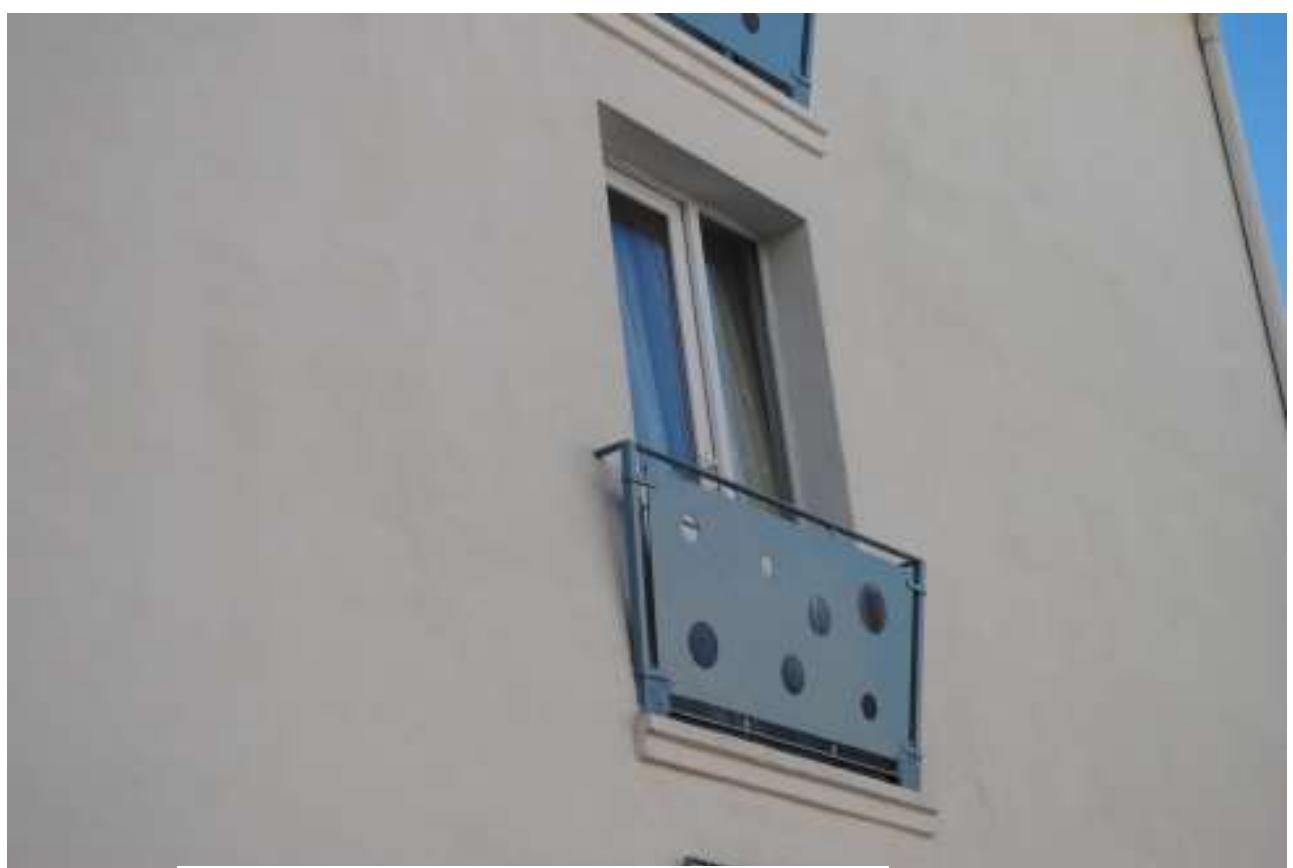

Figure 6. Ankara Balcony Railings, District 4 (Esat)

Source: The author's archive.

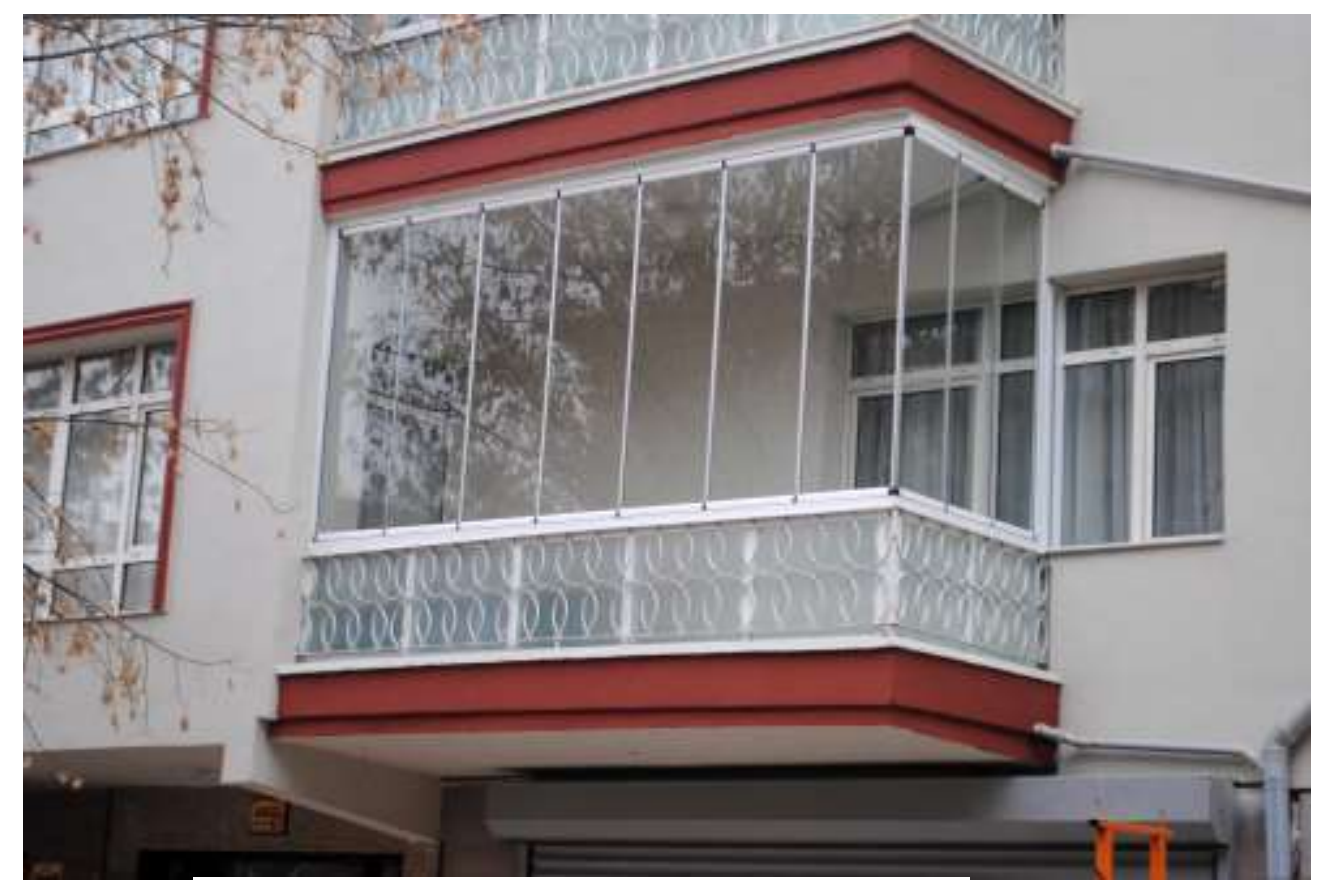

Figure 7. Ankara Balcony Railings, District 5 (Anıttepe)

Source: The author's archive.

Although, balcony railings have a rather obvious function of firstly preventing from falling down, acting as a barrier; secondly hiding the balcony space leastwise ensuring its privacy; their grammar reveals the hints of ornament. In terms of both function and imagery, the railings fulfil the role assigned on them. It is also observed that these elements have been employed to provide dynamism to 
façades. They help increase the readability and tectonics. As a whole, they help extend the formal repertoire of apartment building architecture in the city of Ankara forming a consistent grammar. The communicative role of the ornament, in this case, the balcony railings, is articulated in the tension between seeing the façade as a written page and the destruction of its content through repetition and patterning. This pattern throughout the city creates the continuity of architectural language in the sense that "ornament usually associates with the façades or the plasticity of buildings yet it also establishes relationships with the building and the urban fabric." $" 45$

\section{Conclusions}

As put forward by Benjamin, "Every image of the past that is not recognized by the present as one of its own concerns threatens to disappear irretrievably." 46 Tapan points out to the most important element that saves a society from being nomad as the instinct to add new values to all the local values in the past. In other words, when a society is established, it takes place by adopting the values that make up the environment. ${ }^{47}$ In this respect, this study aims to reveal that balcony railings of Ankara apartments (1950-75) as a representative element would remind Ankara dwellers of their shared memory related to their physical, social and economic environment. These elements can also be regarded as components of "architectural heritage". Architectural heritage is not just comprised of buildings themselves, but all parts of the building -from architectural interiors to balcony railings- are considered a part of this heritage, reflecting the design and architectural understanding of the period in which it was built. It is important to record these components, which are relatively difficult to preserve being just contributing as one part of the whole.

\section{Bibliography}

Alkan Korkmaz, Sevinç, Gizem Özmen, Yasemin Oksel, and Ebru Bengisu. “[En]Closed Balconies: Something Extra." In Proceedings of ARCHDESIGN '15. Edited by $\mathrm{H}$. Tulum. İstanbul: DAKAM Yayınları, 2015.

Altan Ergut, Elvan. "Cumhuriyetin Mekanlar1/Zamanlar//Insanları: Mimarlık Tarihyazımı Üzerine Bir Değerlendirme" (Spaces/Periods/People of the Republic: An Evaluation on Architectural Historiography)." In Cumhuriyetin Mekanları/Zamanları/Insanları (Spaces/Periods/People of the Republic). Edited by Elvan Altan Ergut and Bilge İmamoğlu. Ankara: Dipnot Yayınları, 2009, 11-24.

45. Balık and Allmer. "A Critical Review of Ornament in Contemporary Architectural Theory and Practice," 2016, 166.

46, As cited in Carel Bertram, Imagining the Turkish House: Collective Visions of Home (Austin: University of Texas Press, 2008).

47, Mete Tapan, "Cumhuriyet Döneminde Doğa ve Kültür Varlıklarını Koruyamamanın Korunması," in 75 Yılda Değişen Kent ve Mimarlık (ed.) Yıldız Sey and Derya Özkan (İstanbul: Tarih Vakfi Yayınları, 1998). 
Balık, Deniz, and Açalya Allmer. "A Critical Review of Ornament in Contemporary Architectural Theory and Practice." A|Z 13, no. 1 (2016):157-169.

Bertram, Carel. Imagining the Turkish House: Collective Visions of Home. Austin: University of Texas Press, 2008.

BK at the Biennale: Anatomy of a Balcony. https://www.tudelft.nl/en/2014/bk/bk-at-thebiennale-anatomy-of-a-balcony/. [Accessed October 25, 2018].

Bozdoğan, Sibel. "Turkey's Post-War Modernism. A Retrospective Overview of Architecture, Urbanism and Politics in the 1950s." In Mid-Century Modernism in Turkey: Architecture across Cultures in the 1950s and 1960s. Edited by Meltem Ö. Gürel. New York and London: Routledge, 2016, 9-26.

Çapaoğlu, Nazan. "Home as a 'Place': The Making of Domestic Space at Yeşiltepe Blocks." Master thesis. Middle East Technical University, 2008.

Cengizkan, Ali. Modernin Saati [Clock of the Modern.] Ankara: Mimarlar Derneği 1927 ve Boyut Yayın Grubu, 2002.

. "Özgünlük ve Tekrarın Tekrarı, Konutta Yeni Gelişmeler ve Nesne Olarak Konut" [Originality and Repetition of Repetition, New Developments in Housing and Housing as an Object.] Arredamento Mimarlık 1 (2004): 106-115.

. "1950'li Y1lllarda Konut: Modernleşme ve Demokratikleşmenin Konut Sorununa Yansimaları" [Housing in the 1950s: Reflections of Modernization and Democratization on the Housing Problem.] In Cumhuriyetin Mekanları/Zamanlarl/ Insanlarl (Spaces/Periods/People of the Republic). Edited by Elvan Altan Ergut and Bilge İmamoğlu. Ankara: Dipnot Yayınları, 2009, 205-234.

Davidovici, Irina. "Abstraction and Artifice." OASE 65 (2004): 100-141.

Grafe, Christoph, Mark Pimlott and Mechtild Stuhlmacher. "Editorial." OASE 65 (2004): $2-5$.

Güner, Deniz. “İzmir'de Modern Konut Mimarlığ1 1950-2006” [Architecture of Housing in Turkey 1950-2006.] Planlama 3 (2006): 123-141.

Gürel, Meltem Ö. "Seashore Readings: The Road from Sea Baths to Summerhouses in Mid-Twentieth Century Izmir." In Mid-Century Modernism in Turkey: Architecture across Cultures in the 1950s and 1960s. Edited by Meltem Ö. Gürel. New York and London: Routledge, 2016, 27-55.

Hamuroğlu, Mehmet. "Balkonlar Üzerine." [On Balconies.] Ege Mimarlık 94, no. 1 (1994): 39.

Healy, Patrick. "Ornament? Now." OASE 65 (2004): 40-63.

Heynen, Hilde. The Architecture and Modernity. A Critique. Cambridge: The MIT Press, 1999.

Le Corbusier. Bir Mimarlı̆̆a Doğru [Toward an Architecture.] İstanbul: Yap1 Kredi Yayınları, 2007.

Loos, Adolf. Ornament and Crime: Selected Essays. UK: Ariadne Pr., 1997.

Misztal, Barbara. Theories of Social Remembering. Berkshire: Open University Press, 2013.

Özkan, Suha. "Modern Türk Mimarlığı için Yeni Bir Giriş." [A New Introduction to Modern Turkish Architecture.] In Modern Turkish Architecture. Edited by Renata Holod, Ahmet Evin and Suha Özkan. University of Pennsylvania Press. 1984.

Şengör, Oya and Sheree Barka. İstanbul'un Balkonlarl [Balconies of İstanbul]. İstanbul: Citlembik Yayınları, 2004.

Smith, Korydon. "Ornament and Austerity." In Introducing Architectural Theory: Debating a Discipline. Edited by Korydon Smith. London: Routledge, 2012, 38-68.

Stuhlmacher, Mechthild. "Vanity and self-will. The Complex, Contradictory Work of Hild Und K." OASE 65 (2004): 26-39.

Tafuri, Manfredo. Architecture and Utopia Design and Capitalist Development. 
Cambridge, Massachusetts and London: the MIT Press, 1976.

Tanyeli, Uğur. Ístanbul 1900-2000. Konutu ve Modernleşmeyi Metropolden Okumak [İstanbul 1900-2000. Reading Housing and Modernization from the Metropolis.] İstanbul: Akın Nalça Yayınları, 2004.

Tapan, Mete. "Cumhuriyet Döneminde Doğa ve Kültür Varlıklarını Koruyamamanın Korunması." [Preserving the Un-Preservation of Nature and Cultural Values during the Republican Period.] In 75 Yılda Değişen Kent ve Mimarlı. Edited by Yıldız Sey and Derya Özkan. İstanbul: Tarih Vakfı Yayınları, 1998, 199-207.

Trilling, James. The Language of Ornament. London and New York: Thames and Hudson, 2001.

Tuna, Zeynep. "Reading Manfredo Tafuri: Architecture and Utopia Design and Capitalist Development." Master thesis. Middle East Technical University, 2002.

Ürger, Ahmet Mucip. "Apartment Block as the Object of the Generic City." Master Thesis. Middle East Technical University, 2004. 
